\title{
АДАПТАЦІЯ СТУДЕНТІВ-ІНОЗЕМЦІВ ДО НАВЧАННЯ В УКРАЇНI
}

\author{
О. В. Тихоновський
}

Запорізький держсавний медичний університет

\section{ADAPTATION OF THE FOREIGN STUDENTS TO EDUCATION IN UKRAINE}

\author{
Zaporizhzhia State Medical University
}

\author{
O. V. Tihonovskiy
}

\begin{abstract}
У даній статті робиться спроба оцінити і систематизувати проблеми адаптації іноземних студентів до повноцінного життя і якісного навчання у ВНЗ України. Узагальнені проблеми психологічної адаптації іноземних студентів до навчання в медичному ВНЗ, зроблено спробу розробок рекомендацій для викладачів по удосконаленню професійно-педагогічного спілкування з іноземними студентами з урахуванням культурологічних, національно-психологічних та соціальних особливостей.
\end{abstract}

The article attempts to assess and classify the main problems of foreign students' adaptation to normal life and quality education at the universities of Ukraine.

Problems of psychological adaptation of foreign students to study in medical higher educational institution are summarized, an attempt of development of recommendations for lecturers in improvement of professionally pedagogic communication with foreign students taking into account cultural, national psychological and social peculiarities was made.

Вступ. 3 кожним роком все більше іноземних громадян приїжджає в Україну для здобуття вищої освіти і кожен іноземний студент об'єктивно проходить процес адаптації. Процес адаптації до студентського життя досить важкий, навіть якщо вчишся у своїй країні. I, звичайно, набагато складніший, якщо вчишся не на Батьківщині. Адаптація включає в себе не тільки оптимізацію функціонування організму, але i підтримку збалансованості в системі “організмсередовище". Процес адаптації реалізується щоразу, коли в системі “організм-середовище” виникають важливі зміни і забезпечує формування нового гомеостатичного стану, що дозволяє досягати максимальної ефективності фізіологічних функцій і поведінкових реакцій. Оскільки організм і середовище перебувають у динамічній рівновазі, а їх співвідношення міняються постійно, отже, також постійно повинен здійснюватися процес адаптації. Оскільки період перебування іноземних студентів в Україні коливається від двох тижнів до кількох років, то можна зрозуміти, наскільки важливий постійний контроль за процесом адаптації. Останній включає в себе безліч аспектів, найбільш важливими з яких є:

() О. В. Тихоновський
- пристосування до нового соціокультурного середовища;

- пристосування до нових кліматичних умов, часу;

- пристосування до нової освітньої системи;

- пристосування до нової мови спілкування, до інтернаціонального характеру навчальних груп і потоків, до культури нової країни тощо [1].

Основна частина. Цілком зрозуміло, що протягом декількох тижнів після приїзду в нову країну особливе напруження відчувають студенти 3 матеріально погано забезпечених сімей та ті, хто звик до надмірної опіки з боку батьків. Вони знаходяться в стані стресу: скаржаться на втрату апетиту, втому, млявість, безсоння, поганий настрій і дратівливість. Треба відзначити, що багато студентів відзначають велику допомогу земляків, які навчаються в університетах на старших курсах.

Крім побутових, кожен іноземний студент відчуває мовні труднощі по приїзді до іншої країни для навчання. Неможливість порозумітися з людьми зі служби сервісу ставить їх у вкрай скрутне становище. Труднощі виникають при купівлі речей або продуктів харчування. Лише за допомогою жестів, міміки і окремих фраз іноземні студенти можуть перший час спілкуватись із громадянами України. Пояснення 
жестами і помилки в побудові фраз викликають сміх і подив, а часом мають непристойний характер, що дуже засмучує і бентежить іноземців [2].

Мало хто звертає на це увагу, однак зміна клімату також є сильним подразником для людини, вона може викликати розлад сну, головний біль, підвищення артеріального тиску, загострити хронічні захворювання. Підвищення та зниження температури, зміна вологості повітря, коливання атмосферного тиску, особливості світлового дня можуть викликати поганий настрій і дискомфорт.

Найбільш швидко перебігає процес адаптації до української кухні. У багатьох країнах, як і в Україні, вживають картоплю, рис, м'ясо та рибу, але використовують більшу кількість приправ. Тому окремі страви виявилися подібними з блюдами рідної кухні, що викликало у студентів (наприклад з Індії) приємне здивування. Хочеться підкреслити, що пристосування до різкої зміни кліматичних умов та їжі змушує людину включати відповідні адаптаційні механізми, що чинить негативний вплив на навчальний процес, відсуваючи його на другий план.

Адаптації студента-іноземця до нового соціокультурного середовища сприяють дві групи факторів: залежні від студента та залежні викладача. 3 боку студента важливі: достатній рівень базової підготовки, рівень знання російської або української мови, індивідуальна здатність до навчання, особливості національного менталітету. Викладач, у свою чергу, повинен бути компетентним у предметі, володіти мовою спілкування і володіти певними особистими якостями. Також одним із важливих аспектів адаптації студентів-іноземців до навчання є розуміння нової системи освіти [3].

Головною умовою успішної загальнобіологічної довузівської підготовки іноземних студентів є швидке і ефективне оволодіння російською або українською мовою. Чим краще засвоюється мова, тим ефективніше адаптація, тим швидше студент перестає соромитися звертатися зі своїми проханнями та запитаннями до вітчизняних громадян і студентів 3 інших країн, тобто спілкуватися стає легше, а значить, і простіше пізнання нового, що дуже важливо. Студенти-іноземці болісно переживають непорозуміння, а тим більше конфлікти з викладачами. На їх думку, найбільш ідеальним “прискорювачем" адаптації є створення атмосфери “доброго дому”, де кожен студент-іноземець “знайшов би себе”.

На жаль, іноді викладачі не хочуть вникати у всі проблеми іноземних студентів через відсутність до- свіду чи вільного часу. Деякі викладачі суб' єктивно ставляться до іноземців, проявляють деяку зневагу, що дуже тонко відчувають іноземці, особливо з мусульманських країн. Іноді виникають ситуації, коли викладач не розуміє студента, оскільки той погано володіє російською мовою, і у нього складається враження, що цей студент погано вчиться. Іноді студенти не встигають записувати лекції, оскільки викладачі диктують дуже швидко [1]. Але більшість викладачів допомагає студентам-іноземцям вирішувати їхні проблеми, підтримує їх у навчанні. Важливим є склад груп. В основному кожна група складається з 8-10 чоловік, завдяки чому викладач може кожному студенту приділити достатньо уваги. Спірним є питання формування груп за національною ознакою. Краще, коли група є інтернаціональною. Як зазначають самі студенти, це дуже стимулює процес вивчення російської мови і процес адаптації до нового середовища взагалі $[4,5]$.

Відносини в групі в іноземних студентів теж складаються по-різному. Деякі товариші по навчанню допомагають писати лекції, складати іспити, готувати доповіді, взагалі ставляться доброзичливо і намагаються допомогти. Але є й такі, хто сміється над поганою російською мовою іноземця, його зовнішнім виглядом, критикує відповіді. Зустрічаються і прояви націоналізму. Багато студентів-іноземців лякаються гуляти містом, ходити в музеї та на екскурсії. Негативний психологічний тиск чинять висловлення і випади місцевих жителів на адресу іноземців у транспорті, в магазинах, на вулиці. Але це поодинокі випадки. Наприклад, в найближчих до гуртожитків i університету магазинах продавці вже звикли бачити іноземців та допомагають їм при виборі та купівлі продуктів.

Іноземні студенти з цікавістю пізнають Україну, людей, звичаї, побут, історію, релігію. Відвідування музеїв, виставок, концертів, драматичних театрів, зустрічі та вечори інтернаціональної дружби зі студентами вузів і коледжів, школярами міста та області також сприяють адаптації іноземних студентів. Подолавши складний період адаптації, іноземні студенти міняються, їх погляди на життя стають іншими, i вони починають цінувати те, що не помічали раніше.

Висновки. Потрапляючи в інше соціокультурне середовище, іноземний студент відчуває необхідність адаптуватися до нього з різних позицій:

- як представник своєї країни, тобто як носій своєї соціокультури, традицій, звичаїв, норм поведінки, системи цінностей; 
- як молода людина, тобто як соціалізована особистість $з$ притаманними їй специфічними особливостями;

- як студент, тобто суб'єкт діяльності педагогічного середовища і як об' єкт впливу цього середовища на нього.

Незважаючи на безліч проблем, які існують в іноземного студента, він, як і всі студенти, намагається провести свій час з користю для себе і для інших.

\section{Списоклітератури}

1. Гришаева Л. И. Введение в теорию межкультурной коммуникации / Л. И. Гришаева, Л. В. Цурикова. - М. : Издательский центр “Академия”, 2006. - 234 с.

2. Филимонова Н. Ю. Предвузовская подготовка иностранных учащихся в рамках непрерывного образования / Н. Ю. Филимонова, А. Е. Годенко // Международное образование в начале XX века : сб. науч. тр. Ч. І. - М. : МАДИ (ГТУ), 2005.- С. 74-78.

3. Ахохова Е. Х. Обучение социально-ролевому взаимодействию в межкультурной коммуникации в условиях дву-
У сучасних умовах навчання іноземних студентів викладач повинен прагнути використовувати всі можливі засоби емоційного та психологічного впливу для створення нормальної атмосфери в навчальній групі, уникати тиску і повчальності, а також авторитарного тону в спілкуванні з учнями. Необхідна технологія навчання, спрямована на академічну, соціально-психологічну та соціокультурну адаптацію іноземних студентів, яка б сприяла успішному міжособистісному, міжкультурному та професійному спілкуванню.

язычного педагогического общения : автореф. дис. канд. пед. наук / Е. Х. Ахохова. - Махачкала, 2004. - 16 с.

4. Зиновьев Д. Б. Повышение педагогического мастерства будущего педагога на основе формирования социокультурной толерантности : автореф. дис. канд. пед. наук / Д. Б. Зиновьев. - Новосибирск, 2000. - 22 с.

5. Тер-Минасова С. Г. Язык и межкультурная коммуникация / С. Г. Тер-Минасова.-М., 2000.-174 с.

Отримано 29.01.15 